\title{
Stability of Diclofenac Sodium Oral Suspensions Packaged in Amber Polyvinyl Chloride Bottles
}

\author{
Ronald F Donnelly, Elena Pascuet, Carmen Ma, and Régis Vaillancourt
}

\begin{abstract}
Background: Prescribing of diclofenac for children usually involves a dose different from commercially available strengths. This drug is available only as tablets, which can be divided only so many times before the dose obtained becomes inaccurate. In addition, children may have difficulty swallowing tablets. For these reasons, a compounding formula for a liquid dosage form is essential to ensure effective delivery of the drug to pediatric patients.

Objectives: To develop a compounding formula for diclofenac sodium and to determine the extended physical and chemical stability of this compound when stored in amber polyvinyl chloride (PVC) prescription bottles under refrigeration and at room temperature.
\end{abstract}

Methods: A suspension of diclofenac sodium $(10 \mathrm{mg} / \mathrm{mL})$ was prepared from commercially available diclofenac sodium tablets, with Ora-Blend as the suspending and flavouring agent. The suspension was packaged in 60-mL amber PVC prescription bottles and stored at either room temperature $\left(23^{\circ} \mathrm{C}\right)$ or under refrigeration $\left(5^{\circ} \mathrm{C}\right)$. Samples were collected on days $0,7,14,21,27,56$, and 93 . Chemical stability was determined using a validated stability-indicating high-performance liquid chromatography method. At each sampling time, the suspensions were checked for changes in appearance (i.e., colour, layering, caking, ease of resuspension), odour, and $\mathrm{pH}$.

Results: The diclofenac sodium suspensions were very stable, retaining at least $99.5 \%$ of the original concentration for up to 93 days, regardless of storage temperature. There were no apparent changes in the physical appearance of the suspensions, nor were there any substantial changes in odour or $\mathrm{pH}$.

Conclusions: Suspensions of diclofenac sodium $(10 \mathrm{mg} / \mathrm{mL})$ were quantitatively stable but difficult to prepare because of the enteric coating of the tablets. Therefore, it is recommended that diclofenac powder be used for the preparation of suspensions. For pediatric use, palatability is a consideration, and a masking agent should be added before administration. An expiry date of up to 93 days is suggested.

Key words: diclofenac sodium, high-performance liquid chromatography, stability, suspension

\section{RÉSUMÉ}

Contexte : La prescription de diclofénac aux enfants requiert généralement une dose qui ne correspond à aucun des dosages disponibles dans le commerce. Ce médicament n'existe que sous forme de comprimés qui ne peuvent être subdivisés que quelques fois sans compromettre l'exactitude de la dose obtenue. En outre, les enfants peuvent avoir du mal à avaler les comprimés. Pour ces raisons, il faut une recette pour la préparation d'une forme pharmaceutique liquide afin d'assurer l'administration effective du médicament aux patients en pédiatrie.

Objectifs : Développer une recette pour la préparation de diclofénac sodique et déterminer la stabilité physique et chimique prolongée de cette préparation lorsqu'elle est conservée dans des flacons en polychlorure de vinyle (PVC) ambré pour médicaments d'ordonnance au réfrigérateur ou à la température ambiante.

Méthodes : Une suspension de diclofénac sodique $(10 \mathrm{mg} / \mathrm{mL})$ a été préparée à partir de comprimés de diclofénac sodique commercialisés avec l'agent de suspension et aromatisant, Ora-Blend. La suspension a été conditionnée dans des flacons en PVC ambré de $60 \mathrm{~mL}$ pour médicaments d'ordonnance, puis entreposée à la température ambiante $\left(23^{\circ} \mathrm{C}\right)$ ou au réfrigérateur $\left(5^{\circ} \mathrm{C}\right)$. Des échantillons ont été prélevés aux jours $0,7,14,21,27,56$ et 93. La stabilité chimique a été déterminée à l'aide d'une épreuve validée par chromatographie liquide haute performance. À chaque prélèvement d'échantillon, les suspensions ont été inspectées visuellement pour déceler tout changement d'apparence (c.-̀̀-d., couleur, stratification, agglutination et facilité de remise en suspension), d'odeur et de $\mathrm{pH}$.

Résultats : Les suspensions de diclofénac sodique sont demeurées très stables, conservant plus de 99,5\% de la concentration initiale pendant une période allant jusqu’à 93 jours, peu importe les conditions d'entreposage. On n'a observé aucun changement évident dans l'apparence des suspensions ni de changement substantiel dans l'odeur ou le $\mathrm{pH}$ des suspensions.

Conclusion : Les suspensions de diclofénac sodique $(10 \mathrm{mg} / \mathrm{mL})$ étaient quantitativement stables, mais difficiles à préparer à cause de l'enrobage entérosoluble des comprimés. Par conséquent, il est recommandé d'utiliser plutôt le diclofénac en poudre. La palatabilité étant un facteur dont il faut tenir compte en pédiatrie, on devrait ajouter un masquant du goût avant l'administration de la préparation. La durée de conservation suggérée est de 93 jours au maximum.

Mots clés : diclofénac sodique, chromatographie liquide haute performance, stabilité, suspension

[Traduction par l'éditeur]

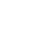




\section{INTRODUCTION}

$\mathrm{N}$ onsteroidal anti-inflammatory drugs (NSAIDs) work by inhibiting the cyclo-oxygenase (COX) enzymes involved in the first step of the inflammation cascade. The pain-relieving property of NSAIDs is due to inhibition of the cyclooxygenase-2 (COX-2) isozyme. However, inhibition of the cyclo-oxygenase-1 (COX-1) isozyme causes gastrointestinal adverse effects. The selective COX-2 inhibitors were developed in an attempt to address this problem by providing pain relief without gastrointestinal toxic effects. ${ }^{1-3}$ NSAIDs are important in the treatment and prevention of mild or moderate pain in children and are highly effective in combination with local or regional nerve block. ${ }^{4}$ Diclofenac sodium is a traditional NSAID that has a slight specificity for COX-2 receptors. ${ }^{1,5}$ Its pharmacokinetic properties include strong binding to protein (99.4\%), a short half-life (about $2 \mathrm{~h}$ ), a low volume of distribution, and weak acidity, meaning that there is a preferential distribution to and persistence in inflamed tissue. This signifies a shorter dwell time and lower concentration in the adverseeffect compartments (such as the liver, kidneys, and gastrointestinal tract), where tissue-protective prostaglandins can recover. ${ }^{6}$ Together, these properties tend to lessen the undesirable gastrointestinal adverse effects related to traditional NSAIDs, including diclofenac sodium, a drug that has been used as an analgesic for pediatric patients undergoing tonsillectomy and adenoidectomy. ${ }^{6-8}$

Doses of medications for children are typically determined according to the patient's weight; as a result, the required dose is usually different from commercially available strengths. At present, diclofenac sodium is available only in tablet form; these tablets can be divided only so many times before the dose obtained becomes inaccurate. Furthermore, children may have difficulty swallowing even a portion of these large tablets. Few compounding formulas are available for suspensions because of the requirement for stability data. Indeed, a search of the medical literature yielded no compounding formulas for diclofenac sodium with stability data. In addition, no oral liquid dosage form for diclofenac sodium is commercially available in Canada.

The objectives of this study were to develop a compounding formula for diclofenac sodium and to test the extended stability of the suspension when stored in polyvinyl chloride (PVC) prescription bottles under refrigeration $\left(5^{\circ} \mathrm{C}\right)$ and at room temperature $\left(23^{\circ} \mathrm{C}\right)$. The intention was to create an accurate, easy-to-prepare dosage form of this medication, with a reasonable expiration date, that would effectively deliver the drug to patients.

\section{METHODS}

\section{Preparation of Suspensions}

Tablets were chosen for this study, rather than powder, in an attempt to develop a formulation that could be easily used by community pharmacists. Test suspensions were prepared with both diclofenac sodium and diclofenac potassium tablets, but in both cases, the resulting formulations were clumpy, and it was difficult to prepare a smooth suspension. We decided to proceed with diclofenac sodium, because the dark maroon colour of the diclofenac potassium suspension was deemed aesthetically displeasing, especially for children.

Forty enteric-coated tablets of commercially available diclofenac sodium (Novo-Difenac, 50-mg tablets, Novopharm Limited, Toronto, Ontario; lot 141102A, expiry January 2009) were used to prepare the suspensions. The nonmedicinal excipients of the tablets were hydroxypropyl methylcellulose, magnesium stearate, maltodextrin, methacrylic acid, microcrystalline cellulose, polyethylene glycol, povidone, pregelatinized starch, silicon dioxide, sodium lauryl sulphate, sodium starch glycolate, synthetic iron oxide black, synthetic iron oxide red, synthetic iron oxide yellow, talc, titanium dioxide, and triethyl citrate.

The tablets were ground to a powder using a mortar and pestle, and the powder was combined with $200 \mathrm{~mL}$ of Ora-Blend (Paddock Laboratories Inc, Minneapolis, Minnesota; lot 7381009 , expiry September 2009) to create a $10 \mathrm{mg} / \mathrm{mL}$ suspension. The criteria for selection of the vehicle were good stabilizing and suspending properties, good palatability, and wide availability, to facilitate the compounding of this suspension in community pharmacies. Ora-Blend, a widely available suspending and flavouring agent, met these criteria. The excipients in Ora-Blend are water, sucrose, sodium phosphate monobasic, sodium carboxymethylcellulose, xanthan gum, carrageenan, glycerine, sorbitol, citric acid, berry flavour PFC F9844, methylparaben, potassium sorbate, and an antifoaming agent. ${ }^{10}$

The diclofenac sodium suspension was divided evenly among six $60-\mathrm{mL}$ amber PVC prescription bottles (Rigo Products, Division of Richards Packaging Inc, Mississauga, Ontario). Three bottles of the suspension were stored at $5^{\circ} \mathrm{C}$ in a refrigerator and 3 were stored at $23^{\circ} \mathrm{C}$. All bottles were protected from light during storage.

\section{Sample Collection}

On days $0,7,14,21,27,56$, and 93, each bottle was shaken for $1 \mathrm{~min}$, to resuspend the material. A 5-mL sample was collected from each bottle using a plastic syringe and then transferred to a glass bottle and stored at $-70^{\circ} \mathrm{C}$ until stability analysis at a later date.

\section{Physical Compatibility}

On each collection day, the suspensions were examined with the unaided eye for any change in appearance (i.e., colour, layering, caking, ease of resuspension) or odour. The $\mathrm{pH}$ was 
monitored with a calibrated $\mathrm{pH}$ meter (Accumet 25, Fisher Scientific Inc, Nepean, Ontario). Buffers at $\mathrm{pH} 4$ (Fisher Scientific Inc; lot SC6236793, expiry September 30, 2008) and pH 7 (Fisher Scientific Inc; lot SC7134746, expiry May 31, 2009) were used to calibrate the meter before each set of tests.

\section{Chemical Stability Study High-Performance Liquid Chromatography System}

The mobile phase for high-performance liquid chromatography (HPLC) was prepared as described in the USP 30 monograph for diclofenac sodium delayed-release tablets. ${ }^{11}$ It consisted of 70\% HPLC-grade methanol (Fisher Scientific Inc; lot 083997) and 30\% phosphate buffer $\mathrm{pH} 2.5$. The phosphate buffer was prepared by combining equal parts of $0.01 \mathrm{~mol} / \mathrm{L}$ monosodium phosphate $(\mathrm{BDH} \mathrm{Inc}$, Toronto, Ontario; lot $115184 / 38578$ ) and $0.01 \mathrm{~mol} / \mathrm{L}$ phosphoric acid (BDH Inc; lot 91892) and then adjusting the $\mathrm{pH}$ to 2.5 with concentrated $o$-phosphoric acid. Diclofenac-related compound A was not used as part of the system suitability testing.

An isocratic pump (model LC-10ATvp, Shimadzu Scientific Instruments Inc, Columbia, Maryland) was used to pump the mobile phase through a reverse-phase C18 5- $\mu \mathrm{m}$, $4.6 \times 250 \mathrm{~mm}$ column (Luna, Phenomenex, Torrence, California; lot 410754 ) at $1.0 \mathrm{~mL} / \mathrm{min}$. A $10-\mu \mathrm{L}$ sample was injected onto the column using an autoinjector (model Sil-10AXL, Shimadzu Scientific Instruments Inc), and a photodiode array detector (model SPD-M20A, Shimadzu Scientific Instruments Inc) was used to monitor the eluted liquid at $280 \mathrm{~nm}\left(\lambda_{\max }\right.$ value). Data were collected and analyzed using Class-VP software (version 7.4, Shimadzu Scientific Instruments Inc).

Each sample was analyzed in duplicate by the HPLC method published by the United States Pharmacopeia. ${ }^{11}$ The internal standard was prepared by diluting $0.1 \mathrm{~mL}$ of diethyl phthalate (99.5\%, Aldrich Chemical Co, St Louis, Missouri; lot $00603 \mathrm{KH}$ ) in $100 \mathrm{~mL}$ of $70 \%$ HPLC methanol. Peak area ratios (diclofenac sodium to internal standard) were used for all calculations.

\section{Validation of HPLC Assay}

Forced degradation samples were used to validate the stability-indicating capacity of the method. A stock solution of diclofenac sodium (British Pharmacopeia grade, $1 \mathrm{mg} / \mathrm{mL}$, Medisca Pharmaceutique Inc, Saint-Laurent, Quebec; lot 20327/P, expiry February 2011) was prepared in HPLC-grade water. The $\mathrm{pH}$ of a $10-\mathrm{mL}$ sample of the stock solution was adjusted to 1.3 with concentrated hydrochloric acid (BDH Inc; American Chemical Society [ACS] grade, lot 120834-78180). To another $10 \mathrm{~mL}$ of stock solution, enough $5 \mathrm{~N}$ sodium hydroxide solution (Fisher Scientific Inc; certified, lot
SC613544, expiry May 2008) was added to reach a pH of 12.4. For the third degradation sample, $1 \mathrm{~mL}$ of $30 \%$ hydrogen peroxide (Fischer Scientific Inc; ACS grade, lot 073191) was added to $9 \mathrm{~mL}$ of stock solution. The acidic and alkaline samples were incubated at $60^{\circ} \mathrm{C}$ in a hot water bath; the oxidized sample was stored at $23^{\circ} \mathrm{C}$. A time 0 sample was set aside for analysis before any of the degradation samples were prepared. Each degradation sample was diluted 1:10 with mobile phase and tested a total of 7 times over a period of 430 h. The purity of the parent peaks in the degradation samples was confirmed by multiwavelength (280 and $230 \mathrm{~nm}$ ) and ultraviolet (UV) spectral analysis $(200-350 \mathrm{~nm})$. A sample of Ora-Blend, diluted 1:10 with mobile phase, was analyzed for interfering peaks.

To further validate the HPLC method, interday variation was determined by preparing a 5-point standard curve on 5 separate days and calculating a coefficient of variance (CV) for each slope and test sample. The standard curve was prepared by diluting an accurate stock solution of diclofenac sodium $(50.6 \mathrm{mg} / 50 \mathrm{~mL}$ of HPLC-grade water) to $0.025,0.05,0.10$, 0.15 , and $0.20 \mathrm{mg} / \mathrm{mL}$ with $70 \%$ methanol. The accuracy of the method was assessed by conducting a recovery study, in which a sample of suspension with known concentration $(101.5 \mathrm{mg} / 10 \mathrm{~mL}$ of Ora-Blend prepared from pure drug) was analyzed. The precision of the method was determined through intraday analysis of 5 replicate samples injected at 3 different times over a 28 -h period. The sensitivity of the method was also determined by analyzing a serially diluted standard solution until linearity was lost or the peak was undetectable.

\section{Stability Study}

On the day of analysis, all samples were allowed to thaw to room temperature (minimum of $2 \mathrm{~h}$ ). Each glass bottle was shaken for $1 \mathrm{~min}$ to resuspend the material. Samples for analysis were prepared by accurately weighing about $1 \mathrm{~g}$ of each thawed sample into separate $10-\mathrm{mL}$ volumetric flasks. A 7-mL volume of $70 \%$ methanol was added to each flask, and the resulting solutions were sonicated for $10 \mathrm{~min}$. The final volume in each flask was adjusted to $10 \mathrm{~mL}$ with $70 \%$ methanol solution. After thorough mixing, a sample from each of the diluted solutions ( 3 solutions for each storage temperature sample day combination) was prepared for assay, as follows: a $10-\mu \mathrm{L}$ sample of the diluted solution was combined with 200 $\mu \mathrm{L}$ of internal standard and $790 \mu \mathrm{L}$ of $70 \%$ methanol solution. Ten microlitres of each mixture was injected into the HPLC system. Each of the 3 samples for each temperature - sampling day combination was assayed in duplicate $(n=6$ for each data point).

The concentration of drug after various periods of storage at $5^{\circ} \mathrm{C}$ or $23^{\circ} \mathrm{C}$ was reported as a percentage of the concentration at time 0 . 


\section{RESULTS}

\section{Physical Compatibility}

The physical appearance and odour of the suspensions did not seem to change over the course of the study. The slight brown colour imparted by the tablets did not seem to intensify. The $\mathrm{pH}$ of the suspensions did not change more than 0.07 units during storage, and remained at about 6.0 (range 6.04-6.11) for the duration of the study.

\section{Chemical Stability Validation of the HPLC Assay}

After $71 \mathrm{~h}$ of exposure to acidic conditions, the diclofenac sodium had degraded to $22 \%$ of the original concentration (Fig. 1B). Conversely, after $430 \mathrm{~h}$ of exposure to oxidizing conditions, $77.1 \%$ of the original concentration remained (Fig. 1D), and after the same duration of exposure to alkaline conditions and storage at $60^{\circ} \mathrm{C}$, about $92 \%$ of the original

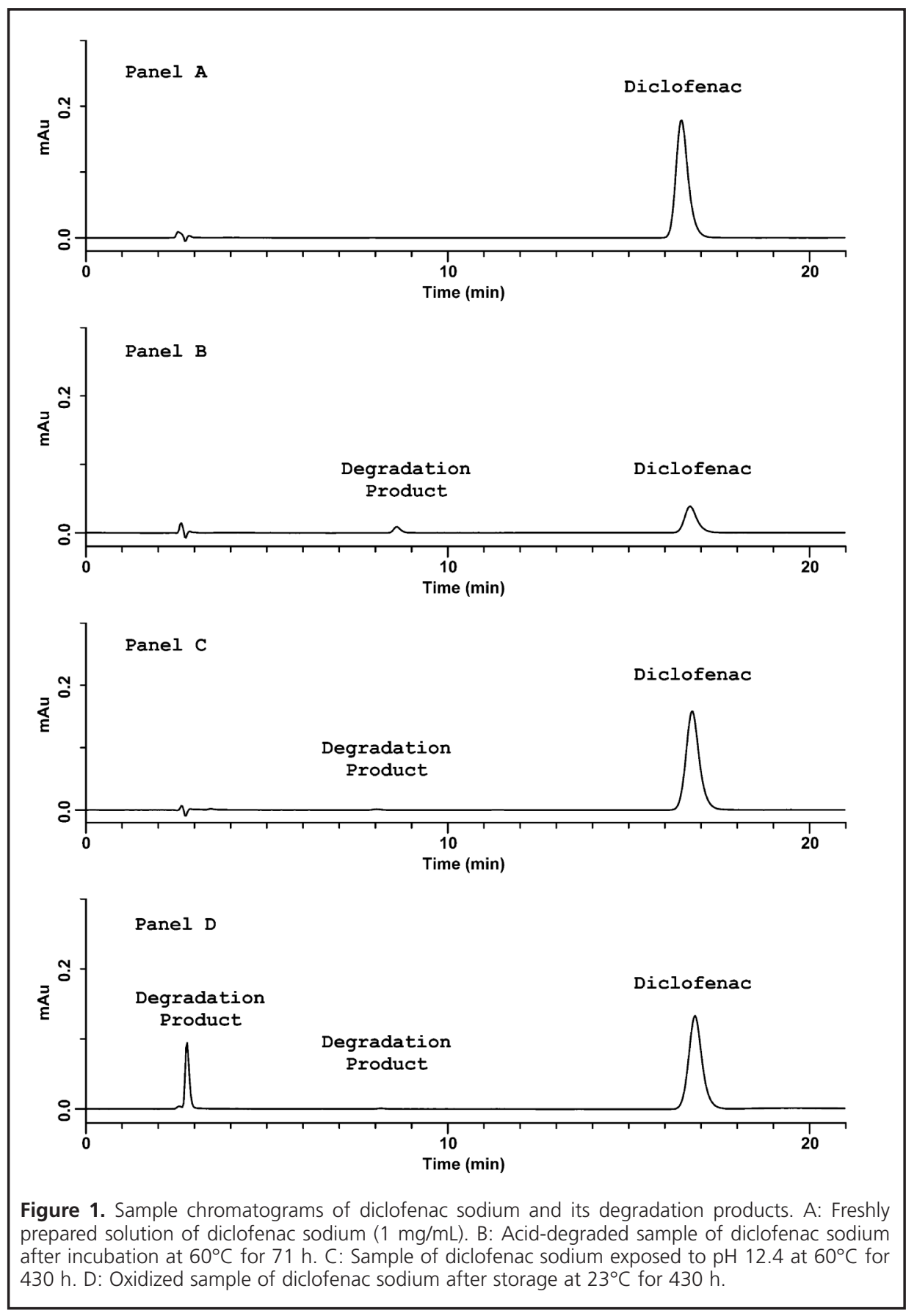


Table 1. Stability of Diclofenac Sodium Suspension $(10 \mathrm{mg} / \mathrm{mL})$ in Ora-Blend Stored at $5^{\circ} \mathrm{C}$ or at $23^{\circ} \mathrm{C}$ with Protection from Light

\begin{tabular}{|c|c|c|}
\hline \multirow[b]{2}{*}{ Study Day } & \multicolumn{2}{|c|}{$\begin{array}{c}\text { Storage Temperature; \% of Initial } \\
\text { Concentration Remaining* (Mean } \pm \text { SD)† }\end{array}$} \\
\hline & Refrigerated $\left(5^{\circ} \mathrm{C}\right)$ & Room Temperature $\left(23^{\circ} \mathrm{C}\right)$ \\
\hline Initial concentration $(\mathrm{mg} / \mathrm{mL})$ & $8.9 \pm 0.13$ & $9.0 \pm 0.28$ \\
\hline Day 7 & $101.1 \pm 1.2$ & $99.5 \pm 1.4$ \\
\hline Day 14 & $99.5 \pm 1.4$ & $101.2 \pm 1.1$ \\
\hline Day 21 & $101.1 \pm 0.5$ & $99.7 \pm 1.3$ \\
\hline Day 27 & $99.8 \pm 1.8$ & $102.6 \pm 0.9$ \\
\hline Day 56 & $105.4 \pm 1.7$ & $100.6 \pm 1.2$ \\
\hline Day 93 & $99.8 \pm 1.1$ & $101.2 \pm 0.9$ \\
\hline
\end{tabular}

concentration remained (Fig. 1C). Analysis of the Ora-Blend blank sample showed no interfering peaks. The UV spectra from the diclofenac sodium peaks in the degradation samples were compared with spectra for reference material (200-350 $\mathrm{nm})$, and the parent peaks were found to be pure. Multiwavelength analysis at 280 and $230 \mathrm{~nm}$ also supported peak purity.

The CVs for the slopes and test samples from the interday testing, on 5 separate days, varied by only $2.02 \%$ and $1.93 \%$, respectively. The average linearity coefficient for the 5 standard curves was 0.9997 . The accuracy of the method was determined to be $97.3 \% \pm 0.68 \%$. Intraday testing revealed that the results changed by only $0.11 \%$ over a 28 -h period. The sensitivity of the assay method was determined to be $20.3 \mathrm{ng}$.

\section{Stability Study}

Regardless of storage conditions, all of the diclofenac sodium suspensions packaged in amber PVC bottles were stable for at least 93 days (Table 1).

\section{DISCUSSION}

A comprehensive search of the published literature yielded no compounding formulas or stability data for suspensions of diclofenac sodium. This lack of information is of particular concern for pediatric patients, who require liquid formulations for accurate delivery of small doses. In addition, information on product stability is important in ensuring that the active ingredient is not affected by long-term storage.

The quantitative results gathered in this study indicate an expiry period of at least 93 days for diclofenac sodium suspension prepared with Ora-Blend and stored either under refrigeration or at room temperature. However, the measured initial concentration of the suspension was determined to be about $9 \mathrm{mg} / \mathrm{mL}$, rather than the intended $10 \mathrm{mg} / \mathrm{mL}$. One possible explanation for this discrepancy is that the difficulty of crushing the tablets (because of their enteric coating) prevent- ed ease of solubility in the suspension. According to the Merck Index, ${ }^{12}$ the solubility of diclofenac sodium is greater than 9 $\mathrm{mg} / \mathrm{mL}$ in deionized water ( $\mathrm{pH} 5.2$ ), but there might not have been enough free water in the Ora-Blend excipients to totally dissolve the diclofenac sodium in the suspensions prepared in this study. However, the fact that all measured values for initial concentration were similar suggests that the suspension was homogeneous. The accuracy of the method was $97.3 \%$, and the discrepancy of $2.7 \%$ was probably a result of compounding error caused by air bubbles in the Ora-Blend.

Qualitative concerns about this preparation included its extremely bitter taste and the clumpy texture of the suspension (the latter of which might have been caused by the excipients in the tablets). Nonetheless, the quantitative results suggest that the suspension is very stable. Therefore, although compounding of suspensions of diclofenac sodium for oral administration appears to be a suitable method for pediatric dosing, we recommend that diclofenac sodium powder be used, rather than tablets. Depending on the patient population, palatability of the suspension must also be considered, so the administration of a masking agent before administration of the drug is recommended.

\section{References}

1. Henry D, Lim LL, Garcia Rodriguez LA, Perez Gutthann S, Carson JL, Griffin M, et al. Variability in risk of gastrointestinal complications with individual non-steroidal anti-inflammatory drugs: results of a collaborative meta-analysis. BMJ 1996;312(7046):1563-1566.

2. Jüni P, Rutjes AW, Dieppe PA. Are selective COX 2 inhibitors superior to traditional non steroidal anti-inflammatory drugs? BMJ 2002;324(7349): 1287-1288.

3. Patrono C, Patrignani P, Garcia Rodriguez LA. Cyclooxygenase-selective inhibition of prostanoid formation: transducing biochemical selectivity into clinical read-outs. J Clin Invest 2001;108(1):7-13.

4. Kokki H. Nonsteroidal anti-inflammatory drugs for postoperative pain: a focus on children. Paediatr Drugs 2003;5(2):103-123.

5. Mitchell JA, Warner TD. Cyclo-oxygenase-2: pharmacology, physiology, biochemistry and relevance to NSAID therapy. Br J Pharmacol 1999; 128(6):1121-32.

6. Rømsing J, Ostergaard D, Drozdziewicz D, Schultz P, Ravn G. Diclofenac or acetaminophen for analgesia in paediatric tonsillectomy outpatients. Acta Anaesthesiol Scand 2000;44(3):291-295. 
7. Mendham JE, Mather SJ. Comparison of diclofenac and tenoxicam for postoperative analgesia with and without fentanyl in children undergoing adenotonsillectomy or tonsillectomy. Paediatr Anaesth 1996;6(6):467473.

8. Tawalbeh MI, Nawasreh OO, Husban AM. Comparative study of diclofenac sodium and paracetamol for treatment of pain after adenotonsillectomy in children. Saudi Med J 2001;22(2):121-123.

9. Compendium of pharmaceuticals and specialties, online version (e-CPS). Ottawa (ON): Canadian Pharmacists Association, 2008. [URL still to come]

10. Material safety data sheet - Ora-Blend. Minneapolis (MN): Paddock Laboratories; 2005 Apr 25.

11. Diclofenac sodium delayed-release tablets monograph. In: USP 30-NF 25. Rockville (MD): United States Pharmacopeial Convention; 2008. p. 1943.

12. Merck index, version 12:3 [CD-ROM]. 12th ed. Whitehouse Station (NJ): Merck \& Co, Inc; 2000.
Ronald F Donnelly, MSc(Chem), BSC(Pharm), is Product Development Pharmacist with the Department of Pharmaceutical Sciences, The Ottawa Hospital (Civic Campus), Ottawa, Ontario.

Elena Pascuet, MSc, is Pharmacy Project Coordinator with the Department of Pharmacy, Children's Hospital of Eastern Ontario, Ottawa, Ontario.

Carmen Ma, BSCPhm, is a Critical Care Pharmacist with the Department of Pharmacy, Children's Hospital of Eastern Ontario, Ottawa, Ontario.

Régis Vaillancourt, PharmD, is the Director of Pharmacy with the Children's Hospital of Eastern Ontario, Ottawa, Ontario.

\section{Address correspondence to:}

Ronald F Donnelly

Department of Pharmaceutical Sciences

The Ottawa Hospital

1053 Carling Avenue

Ottawa ON K1Y 4E9

e-mail: rdonnelly@ottawahospital.on.ca

Acknowledgements

This project was funded externally by the Medbuy Corporation Endowment/Bursary 2007 Fund.

\section{Reminder: the CJHP is now available online}

The Canadian Society of Hospital Pharmacists (CSHP) would like to remind readers about the online hosting platform now available for the Canadian Journal of Hospital Pharmacy (CJHP).

Our members and CJHP subscribers made it clear that an easy-to-use and fully searchable electronic version of the CJHP is important to them. The new CJHP website, launched in April 2009, uses Open Journal Systems (OJS) software to bring you each issue in a clear and readable electronic format. The intuitive OJS platform offers full searching of the CJHP archives that are available to date. Currently, the CJHP online has a complete archive of issues from 2000 to the present, with plans to add more issues from earlier volumes in the future.

CSHP recently announced it would be extending the open access to all of the CJHP archives and current issues for 2010! We encourage members and subscribers to spread the word about this free trial, especially to any colleagues who are not yet members of CSHP or who do not subscribe to the CJHP.

The new electronic CJHP is available at: www.cjhp-online.ca. All users will need to register to use the OJS system using the "Register" link in the top menu bar.

If you have any questions, please feel free to contact Sonya Long, CSHP's Publications Administrator, by phone at 613-736-9733 ext. 228 or email at slong@cshp.ca. 